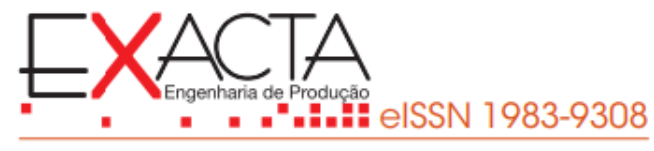

\title{
NEW PRODUCT DEVELOPMENT ABILITY AND INTERNATIONAL INOVATIVENESS: AN EMPIRICAL STUDY ON BRAZILIAN EXPORTING COMPANIES
}

\section{HABILIDADE EM DESENVOLVIMENTO DE NOVOS PRODUTOS E INOVATIVIDADE INTERNACIONAL: UM ESTUDO EMPÍRICO SOBRE EMPRESAS EXPORTADORAS BRASILEIRAS}

Recebido em: 17 mar. 2020

Aprovado em: 13 jul. 2020

Versão do autor aceita publicada online: 13 jul. 2020

Publicado online: 18 jun. 2021

\section{Como citar esse artigo - American Psychological Association (APA):}

Panizzon, M., Milan, G. S., Dorion, E. C. H. \& Olea, P. M. (2021, out./dez.). New product development ability and international inovativeness: an empirical study on brazilian exporting companies. Exacta. 19(4), 954-977. https://doi.org/10.5585/exactaep.2021.16814.

Submeta seu artigo para este periódico $\beta$

Dados Crossmark 


\title{
NEW PRODUCT DEVELOPMENT ABILITY AND INTERNATIONAL INOVATIVENESS: AN EMPIRICAL STUDY ON BRAZILIAN EXPORTING COMPANIES
}

\author{
HABILIDADE EM DESENVOLVIMENTO DE NOVOS PRODUTOS E INOVATIVIDADE \\ INTERNACIONAL: UM ESTUDO EMPÍRICO SOBRE EMPRESAS EXPORTADORAS \\ BRASILEIRAS
}

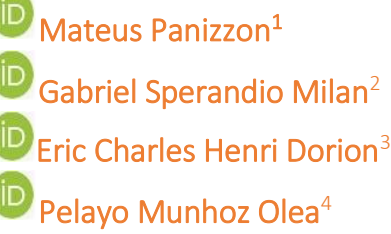

Abstract: The focus of this research is to evaluate the relationship between New Product Development Ability (NPDA) and International Innovativeness through a cross-sectional survey of 167 Brazilian manufacturing and exporting companies, from a medium and large size sample of companies of the metal-mechanic and automotive sectors in Brazil. The analysis was developed through cluster analysis and analysis of variance techniques. The results show that companies with greater level of NPDA have a significantly greater level of International Innovativeness, in low, medium, and high-performance clusters. NPDA also positively relates with export intensity performance. NPDA is proposed as a fundamental process, both business and industrial, for manufacturing companies' competitiveness trought innovation.

Keywords: Innovation strategy. New product development. Manufacturing. Technology management.

Resumo: O foco desta pesquisa é avaliar a relação entre a New Product Development Ability (NPDA) ou Habilidade em Desenvolvimento de Novos Produtos (HDNP) e Inovatividade Internacional por meio de um estudo transversal com 167 empresas brasileiras de manufatura e exportadoras, de uma amostra de médio e grande porte de empresas do setor metal-mecânico e setores automotivos no Brasil. A análise foi desenvolvida por meio de técnicas de análise de cluster e análise de variância. Os resultados mostram que empresas com maior nível de NPDA possuem um nível significativamente maior de Inovatividade Internacional, em clusters de baixo, médio e alto desempenho. O NPDA também se relaciona positivamente com o desempenho da intensidade de exportação. NPDA é proposto como um processo fundamental, tanto comercial quanto industrial, para a competitividade das empresas de manufatura via inovação.

Palavras-chave: Estratégia de inovação. Desenvolvimento de novos produtos. Manufatura. Gestão de tecnologia. 


\section{Introduction}

Why do some manufacturing industries have a greater ability to develop, launch, and systematically introduce more skillfully new products into the international market than their competitors? The motivation to address this issue is based on two premises. The first premise considers a globalization scenario where the capacities for the development of new products become increasingly necessary (Slater, Mohr, \& Sengupta, 2014), and where competitiveness should not only come from a unique cost reduction strategy (Kaminski, Oliveira, \& Lopes, 2008; Cooper, Edgett, \& Kleinschmidt, 2001). The second premise suggests that to effectively compete in the global market, a firm must develop capacities that lead to a greater performance in the development and introduction of new products (Holahan, Sullivan, \& Markham, 2014; Lee, Ling, \& Wong, 2011). Both premises have come to unfold a source of a potential competitive advantage and productivity, as observed by Hana (2013) and Crespi and Zuniga (2012).

Moreover, given that such competition occurs in turbulent environments and with uncertainty, demanding capacities of change and adaptation, and where knowledge becomes the main factor of production (Cordes \& Hülsmann, 2014; Afgan \& Carvalho, 2010), a greater understanding of how the ability to develop new products can contribute to a leadership in international innovation is an object and interest of study both by the academy (Goedhuys \& Veugelers, 2012), by the government and the business sectors (Sun \& Du, 2010; Wang \& Kafouros, 2009; Wan, Ong, \& Lee, 2005).

In that context, this research evaluated the relationship between the New Products Development Ability (NPDA), as the ability to develop, launch, and systematically introduce more skilfully new products into the international market than their competitors, and International Innovativeness, in manufacturing technology-based companies in Brazil. Since the manufacturing industry is an important component of the GDP and the country development strategy, understanding the product innovation capability becomes relevant for both academic and industrial policy development.

\section{Theory}

\subsection{New Products Development Ability and New Products Development Process}

To understand the concept of New Products Development Ability (NPDA), it is necessary to expose the contextualization of the field of New Products Development Process (NPDP). While the New Products Development Ability (NPDA) measures the ability of a company to develop, launch and systematically introduce more skillful new products than its competitors in a specific market (Panizzon, Milan, Dorion, \& Coallier, 2020; Perin, Sampaio, Barcellos, \& Kügler, 2010; Vorhies, Morgan, \& Autry, 2009; Menguc \& Auh, 2009; Subramaniam \& Youndt, 2005), the NPDP can be understood as a set of 
steps that, by excluding the manufacturing aspect in the model, it aims to take a new product to its market and it involves all the aspects, ranging from the product creation and its evaluation, to the product launch (Cooper, 2019; Bhuiyan, 2011; Cooper \& Edgett, 2008; Cooper, 1990). Those stages are the subject of continuous research since the leading organizations of different scales try to model the NPDP steps more closely, by relating them to their organizational objectives and peculiarities (Holahan, Sullivan, \& Markham, 2014). Essentially, some conclusions can be drawn from a comparison made between the main NPDP phases listed by different authors, as observed in Figure 1. A review from the literature of the different models demonstrates the existence of an initial phase of ideation in the period of 1980's, which includes some research focusing on basic analysis and specific filters of those ideas. A second moment offers a more detailed, technological and market analysis, which provides support for the design, development, and prototyping steps, and which is followed by consumer testing and launch in the market. In this second part, the models, such as the one of Carson, Wuand Moore (2012), point out that improvements in the performance of new product development result from an organization that establishes the mechanisms to deal not only with such volatility or turbulence but also with the ambiguity of information. Therefore, it is possible to verify in the area of NPDP that the advances in research do not necessarily translate only into aspects related to the process stages, but also to its context (Cooper, Edgett, \& Kleinschmidt, 2002) that include the use of Gates as decision-making references, to advance to later stages, and formats of process flexibility (Cooper, 2008).

Figure 1

Comparison between NPDP stages

\begin{tabular}{|c|c|c|}
\hline $\begin{array}{l}\text { Booz, Allen and } \\
\text { Hamilton (1982) }\end{array}$ & Cooper and Edgett (2008) & $\begin{array}{c}\text { Durmusoglu, Calantone } \\
\text { and McNally (2013) }\end{array}$ \\
\hline $\begin{array}{ll}\text { - } & \text { New product strategy } \\
\text { - } & \text { Idea Screening } \\
\text { - } & \text { Idea generation } \\
\text { - } & \text { Design and development } \\
\text { - } & \text { Test } \\
\text { - } & \text { Commercialization }\end{array}$ & $\begin{array}{ll}\text { - } & \text { Preliminary market assessment } \\
\text { - } & \text { Preliminary technological assessment } \\
\text { - } & \text { Suppliers evaluation } \\
\text { - } & \text { Market research (size, segmentation and } \\
\text { - } & \text { VoC - Voice of the customer) } \\
\text { - } & \text { Value evaluation for the client } \\
\text { - } & \text { Product definition } \\
\text { - } \quad \text { Business and financial analysis }\end{array}$ & $\begin{array}{l}\text { - Discovery Tasks: } \\
\circ \quad \text { Generating Ideas } \\
\circ \quad \text { The Preliminary Market Assessment } \\
\circ \quad \text { The Preliminary Technology } \\
\text { Assessment } \\
\text { - Development Tasks: } \\
\circ \quad \text { Detailed market assessment } \\
\circ \quad \text { Detailed technological assessment } \\
\circ \quad \text { Concept / Prototyping } \\
\text { - Marketing Tasks: } \\
\circ \quad \text { Consumer testing } \\
\circ \quad \text { Ramp up (start of commercial } \\
\text { production) } \\
\circ \quad \text { Launching on the Market }\end{array}$ \\
\hline
\end{tabular}

Source: Prepared by the authors.

Previous research has pointed out that well-known routines, rigid rules and structures tend to lead employees to a lower level of creativity (Amabile \& Conti, 1999). In such context of formalization, especially in relation with the NPDP, a relevant discussion on creativity and entrepreneurship arises 
between systematization and trial and error (Brattström, Löststen, \& Richtnérer, 2012). Clark and Fujimoto (1991) argued that the NPD process requires a balance between control and freedom, precision and flexibility, individualism, and teamwork. For Gilson, Mathieu and Shalley (2005), the objective of systematic processes, as opposed to trial-and-error processes, is to reduce the variability associated with the task, promoting greater efficiency. For the authors, creativity broadens and optimize the fit between the team's efforts and the results instead of enhancing the implementation of explicit organizational rules by detailing how and by whom the work should be developed. This fundamental distinction suggests that creativity and standardized processes are mutually exclusive. However, the authors identify in their research that creativity can even be more efficient in standardized processes. However, the empirical work of Brattström, Löfsten and Richtnér (2012) responds to questions raised by Gilson, Mathieu and Shalley (2005), suggesting that systematized processes and formalized structures do not necessarily reduce creativity, however, generate a positive relation between creativity and systematized processes when mediated by goodwill trust. More specifically, the authors point out that the trust variable is an important and explanatory element of NPDP with an existing convergence between systematization and creativity. From such premises, it becomes important to analyze the form of operation of each construct, which have been measured from four indicators that are part of the Organizational Creativity context. It deals with aspects regarding the acceptance of criticism, the atmosphere of support, the understanding of the company and the atmosphere of everyone to develop their best at work (Amabile, 1996; Ekvall, 1997; Bstieler, 2006; Akgün, Keskin, \& Byrne, 2010). The Brattström, Löfsten and Richtnér (2012) model introduces three important aspects in the NPDP analysis, such as the relation between creativity, trust and level of systematization of the process. The aspect of systematization is emphasized by the authors as a function of tradeoff between increasing or reducing the variability of activities. While reducing the variability and standardization of the process, it can make it more efficient, with less uncertain operations. It can also be prone to exploit existing knowledge to develop incremental innovations, greater variability that can be beneficial in terms of exploiting new knowledge for the creation of radical innovations, as new products face new problems requiring new information and imaginative approach to their solution. This model presents three main aspects: the first one is that the NPDP is analyzed through its systematization, nor by the steps that should matter, since companies have their own contingencies, and they can adopt different process configurations. The element of creativity as measured is not also expressed in terms of outcomes, but in terms of the organization's orientation toward creativity. Leenders, Van Engelen and Kratzer (2007) note that any NPD process requires some level of creative effort, and that bearing creative performance is of paramount importance. Integration and communication between the NPD teams are essential for efficiency and team intuition, generating capacity for new product success and launch speed in turbulent markets (Dayan \& Elbanna, 2011). 
In addition, a higher level of Organizational Creativity contributes to a company having richer interactions among its team, which positively influences the idealization phases such as NPDP input and performance in innovation (Dixit \& Nanda, 2011). Bharadwaj and Menon (2000) pointed out that there is a positive relationship between the level of organizational (and individual) creativity and a higher level of performance in the organizations. Such statement is first related to Rosenbusch, Brinckmann and Bausch (2010) work and theirmeta-analysis that observed a more formalized NPD process related to orientation toward innovation and product innovation in large companies. Any organization can achieve a higher performance in Product Innovation through a structured NPDP strategy implementation. Second, this view is corroborated by Zhou and Uhlaner (2009), where the orientation toward innovation through NPDP represents a mediating variable between external knowledge acquisition and internal sharing practices and innovation performance in SMEs. As the scope of this study involves medium and large companies, this basis of understanding is used to support relationships. To better expose research in the field of New Product Development, it is important to distinguish between 1) the NPDP performance as an output and 2) the NPDP performance as a process, since both approaches are present in the literature. Many articles interpret NPDP Performance in terms of output measures such as the number of innovative products launched (Park \& Kim, 2013; Bendoly, Bharadwaj, \& Bharadwaj, 2012), although this measure is confused with the concept of performance in product innovation. The measurement approach dealing with NPDP results, in terms of process, is based on the concept of the development of new products, through the studies conducted by Song and Parry (1997), Millson and Wilemon (2002); Kim, Wong and Eng (2005), Lee and Wong (2010), Li and Huang (2012), Millson (2012) and Koksal (2014). In such a perspective NPDP groups process and product dimensions together (development, launch and the introduction of innovative products in the market). Some contributions to the area deal with measurement approaches. Theyare presented and discussed in chronological order from Song and Parry (1997), Millson and Wilemon (2002), Millson (2012), Millson (2012) and Koksal (2014). The work of Song and Parry (1997) conducted a comparative study between the United Statesand Japan, where they evaluated through a proficiency scale the level of development of NPD activity, from an undeveloped to a developed scheme. The model presents the phases of Development, Business Proficiency and Market Opportunity Analysis, Technological Development Proficiency, Proficiency in Product Testing, as well as Marketing Proficiency, which constitutes the basic and structural dimensions of the New Product Development Process. Among several scales in the literature that analyze the process or its outputs, a one-dimensional scale of NPDP was proposedfrom theory (Vorhies, Morgan, Autry, \& 2009; Menguc \& Auh, 2009, Subramaniam \& Youndt, 2005) adapted to the international market, where the study does not seek to operationalize the relationship between NPDP in Product Innovation, since there is already established evidence in the literature about the positive relationship between those two aspects (Bharadwaj \& Menon, 2000; Im, Montoya, \& Workman, 2013). 
Therefore, since NPDA can beconsidered a capability of developing, launch, and sustain active product development, to operationalize New Products Development Ability measurement, the construct is defined by the following indicators according to the scale applied by Perin et al. (2010): (i) the effectiveness in the development of new products, (ii) the ability to successfully launch new products, and (iii) active product development to maintain leadership in the specific market (Vorhies, Morgan, \& Autry, 2009; Menguc \& Auh, 2009; Subramaniam \& Youndt, 2005).

\subsection{International inovativeness}

In this study, the International Innovativeness is based on the International Entrepreneurial Orientation construct (Covin \& Miller, 2014; Dimitratos, Voudouris, Plakoyiannaki, \& Nakos 2012), which is defined by the dimensions of proactiveness, risk aversion and innovativeness in international markets. The measurement of innovativeness of this scale considers three variables: a) in the last five years, the company introduced several new product lines in the international market; b) in the last five years, the changes in the product lines offered in the international market were radical; c) in dealing with competitors in the international market, the company is often the first to introduce new products and/orservices, administrative techniques or operational technologies. Therefore, the dimension of International Innovativeness, in essencence measures the International Product Innovation Performance. From this perspective, the study proposes to analyze the relationship between the New Product Development Ability and the International Innovativeness.

\section{Method}

\subsection{Strategy}

The method was quantitative by using a strategy with a single cross-sectional survey (Hair Jr., Black, Babin, \& Anderson, 2009). According to figure 2, the NPDA and IEO scales started from Dimitratos et al. (2012) and Vorhies, Morgan and Autry (2009). Secondary analysis included the variables related to Learning Capability (Sok, O'cass, \& Sok, 2013) and Organizational Creativity (Boada-Grau, SánchezGarcía, \& Prizmic-Kuzmica, 2014). The instrument was validated by six specialists from the fields of Learning, Entrepreneurship, New Product Development, and Innovation, as well as research methods. 
Figure 2

Scales utilized for the research

\begin{tabular}{|c|c|c|c|}
\hline Constructs & Acronyms & Authors & Original Indicadors \\
\hline $\begin{array}{c}\text { New Products } \\
\text { Development Ability }\end{array}$ & NPDA & $\begin{array}{c}\text { Vorhies, Morgan, } \\
\text { Autry (2009) }\end{array}$ & $\begin{array}{c}\text { (3 adapted for the international } \\
\text { market) }\end{array}$ \\
\hline $\begin{array}{c}\text { International Entrepreneurial } \\
\text { Orientation }\end{array}$ & IEO & $\begin{array}{c}\text { Dimitratos, Voudouris and } \\
\text { Plakoyiannaki (2012) }\end{array}$ & 7 \\
\hline International Inovativeness & IEO_LII & $\begin{array}{c}\text { Dimitratos, Voudouris and } \\
\text { Plakoyiannaki (2012) }\end{array}$ & 3 were adopted for IEO \\
\hline Learning capacity & LEA_C & Sok, O'cass and Sok (2013) & 6 \\
\hline Organizacional Creativity & ORG_CRE & $\begin{array}{c}\text { Boada-Grau, Sánchez-García } \\
\text { and Prizmic-Kuzmica (2014) }\end{array}$ & 4 \\
\hline Reconfiguration capacity & REC_C & Hawass (2010) & 4 \\
\hline Technological Capacity & TEC_C & $\begin{array}{c}\text { Tzokas, Kim and Akbar } \\
(2015)\end{array}$ & 4 \\
\hline
\end{tabular}

Source: Elaborated by the authors.

\subsection{Sample, data collection, and procedures for multivariate analysis}

The final sample collected included 167 companies within the Brazilian metal-mechanic sector. They were selected from the criteria of size and segment, from a database of the Ministry of Industry. With this database, an research institute applied the survey using telephone, interviewing the respondents, and web forms, when necessary. The final data collection comes from medium and largesized companies located in the States of Rio Grande do Sul, Santa Catarina, Paraná and São Paulo, Brazil. These regions host the largest number of companies in themetal-mechanic sector, accounting for $30 \%$, $23 \%, 28 \%$ and $33 \%$, respectively, of the total companies population in this segment.

To respond to the objectives of this study, the first step consisted in performing the datascreening procedures and assumption's tests required for the application of the multivariate analysis (Malhotra, Birks, \& Wills, 2012). The software used for the analysis was SPSS ${ }^{\circledR}$ Statistics 20 (uni and multivariate analysis). The tests of 1) normality (asymmetry, Kurtosis, Kolgomorov-Smirnov); 2) homoscedasticity (Levene); 3) linearity (Pearson) and 4) multi-collinearity (VIF- Variance Inflaction Factor and tolerance factor) were carried out to verify hat the data attend the assumptions for the multivariate analysis (Hair Jr. et al., 2009). 


\section{Results and discussions}

\subsection{Sample Profile}

The sample meets the requirements for the development of the analysis considering the geographical and size dimensions of the four selected States. The final sample of 167 medium and large export companies hasan average of 46 years of activities, 20 years of export experience and an average of $35 \%$ of exports share on their annual sales. This sample represents a portfolio of more than 160,000 customers, a structure of more than 180,000 employees, aggregate annual revenue over 50 billion Brazilian Reais (17 billion USD) and a 9\% average profit margin. This group of companies presented an average launch of 22 new items on the market in the last two years. Regarding export experience (date of firstexport), $3 \%$ of the companies have exported since the 1960s; $8 \%$ have exported since the 1970s; $12 \%$ have exported since the 1980s; $24 \%$ have exported since the 1990s; $40 \%$ have been exporting since the 2000s; And 13\% export from 2010 or beyond. As for the number of countries for which they export, $60 \%$ of companies export to 10 countries, 30\% between 11 and 50 countries and 5\% export to more than 51 countries. In the personnel structure for prospecting for the international market, $74 \%$ of them have up to 10 employees; $21 \%$ have between 11 and 50 employees and $5 \%$ have over 50 employees dedicated to this activity. In this sense, the sample meets the requirements of the exporter profile for the analysis. Table 1 shows the total number of companies participating in the survey after the datascreening procedures, by State and by category, considering companies with lower and higher degrees of internationalization, given the categories of the questionnaire in relation to the concentration of the operations in the national or international market, as well as its export intensity. Of those, $70 \%$ reported being of themetal-mechanical segment (machinery, tooling), $20 \%$ of the automotive and $10 \%$ of the electric / electronic, which comprises the National Economics Activities Classification that comprises the sector proposed for the analysis of this research.

Table 1

Sample profile

\begin{tabular}{l|c}
\hline \multicolumn{1}{c|}{ Company Profile Description } & Total \\
\hline $\begin{array}{l}\text { The company has its operations concentrated in the Brazilian territory but } \\
\text { attends sporadic orders for export. }\end{array}$ & 39 \\
\hline $\begin{array}{l}\text { The company has its operations concentrated in the Brazilian territory and it } \\
\text { has regular exports, within the percentage described in the first question. }\end{array}$ & 73 \\
\hline $\begin{array}{l}\text { The company has some operations established in international territories (sales } \\
\text { subsidiaries or production operations). }\end{array}$ & 24 \\
\hline The company is globalized (extensive operations in international territories). & 31 \\
\hline \multicolumn{1}{c}{ Total } & $\mathbf{1 6 7}$ \\
\hline
\end{tabular}

Source: Prepared by the authors. 
The respondents from the strategic level (CEO, Management) of the company account for $70 \%$ of the sample and the ones from the tactical level (Coordination, Supervision, Analyst) represent 30\% of the participants. In terms of activities in the company, 56\% are from the International Trade (Import and Export) activities, with an average company time of 9 years; $30 \%$ are from Management, Marketing and Sales activities; And 12\% are involved with Processes (R\&D, NPD, Engineering, Operations). In this sense, the respondents are classified in levels or areas of aptitude for understanding of the proposed instrument of data collection.

\subsection{Analysis}

In this study, the International Innovativeness variable (defined as IEO_LII) emerges from the results identified in the exploratory factor analysis (EFA) of the International Entrepreneurial Orientation construct from this study sample (Covin \& Miller, 2014; Dimitratos et al., 2012), which is defined by the dimensions of proactiveness, risk aversion and innovativeness in international markets. Dimitratos et al. (2012) used such scales in their research and a similar behavior in samples of companies from the United States and England, whose international competitiveness in product innovation is greater in this sector than the Brazilian ones, was discovered.

According to Table 2, EFA analysis of the construct with one of the International Entrepreneurial Orientation (IEO) shows that the variables IEO 11, IEO 13 and IEO 14 did not group together with the other variables of the EFA construct, impacting the Cronbach's alpha when analyzed with the seven initial variables. It was therefore sought to better understand the situation by identifying through an exploratory factorial analysis only with the seven variables from this list of IEO indicators, and without any forced decision and by identifying the formation of two factors.

Table 2

\section{EFA from IEO}

\begin{tabular}{|c|c|c|c|}
\hline \multirow{2}{*}{ Variables } & \multicolumn{2}{|c|}{ Component } & \multirow{2}{*}{$\begin{array}{l}\text { Cronbach } \\
\text { Alpha }\end{array}$} \\
\hline & 1 & 2 & \\
\hline IEO 8 - The company favors high risk projects with chances of high returns in the international Market. & ,814 & & \multirow{4}{*}{0,798} \\
\hline $\begin{array}{l}\text { IEO } 9 \text { - In general, the company believes that because of the international competitive environment, } \\
\text { the best way to achieve strategic objectives is through bold and risky decisions. }\end{array}$ &, 811 & & \\
\hline $\begin{array}{l}\text { IEO } 10 \text { - When dealing with international market competitors, the company usually initiates actions } \\
\text { that lead competitors to react. }\end{array}$ &, 710 & & \\
\hline $\begin{array}{l}\text { IEO } 12 \text { - When dealing with competitors in the international market, the company usually seeks to } \\
\text { confront competitors with a highly competitive position. }\end{array}$ & ,613 & & \\
\hline $\begin{array}{l}\text { IEO } 13 \text { - In the last five years, the company introduced several new product lines in the international } \\
\text { market. }\end{array}$ & & ,904 & \multirow{3}{*}{0,772} \\
\hline $\begin{array}{l}\text { IEO } 14 \text { - In the last five years, the changes in the product lines offered in the international market were } \\
\text { radical. }\end{array}$ & & ,757 & \\
\hline $\begin{array}{l}\text { IEO } 11 \text { - In dealing with competitors in the international market, the company is often the first to } \\
\text { introduce new products and/or services, administrative techniques or operational technologies. }\end{array}$ & & ,676 & \\
\hline
\end{tabular}

Source: Elaborated by the authors, based on the results of the SPSS processing. 
From this data, it is possible to draw two perspectives. The first perspective comes from the variables IEO 11, IEO 13 and IEO 14, about International Innovativeness, while the others concern the dimensions of proactivity and risk-taking, which leads to an interpretation. Although the sample is composed of Brazilian medium and large size manufacturing and exporting companies, the results demonstrate a pro-active posture and decision making in international markets, but not necessarily to get results in leadership for innovation in the international markets, since it depends on other internal and external factors, which will impact the behavior of the EFA with the other variables on the correlation results. Therefore, International Innovativeness, according to Cronbach Alpha, will be used as a composed measure for further analysis.

\subsubsection{New Product Development Ability and its relationship with the International Inovativeness}

Considering the question "what is the relationship between NPDA and International Innovativeness," and by using the variables IEO 11, IEO 13, IEO 14 (IEO_LII), three clusters of low, medium, and high level of development were identified. From the ANOVA analysis, it can be noted that there is a positive relationship between the level of development of NPDA and IEO_LII (Figure 3). It suggests an association between the concepts of International Inovativeness, and the New Products Development Ability. This result is key to the research since it gives a clear understanding of the factors influencing NPDA and their predictive function, and they present a positive however not necessarily causal association. The organizations having the highest NPDA score also have a higher performance in the International Inovativeness. This result establishes an important agenda for future studies, and also a contribution with significant managerial contributions to companies delimited in this research environment. That said, another appropriate complementary aspect to investigate the relationship is about NPD Integration. 
Figure 3

Relation between NPDA and IEO_LII

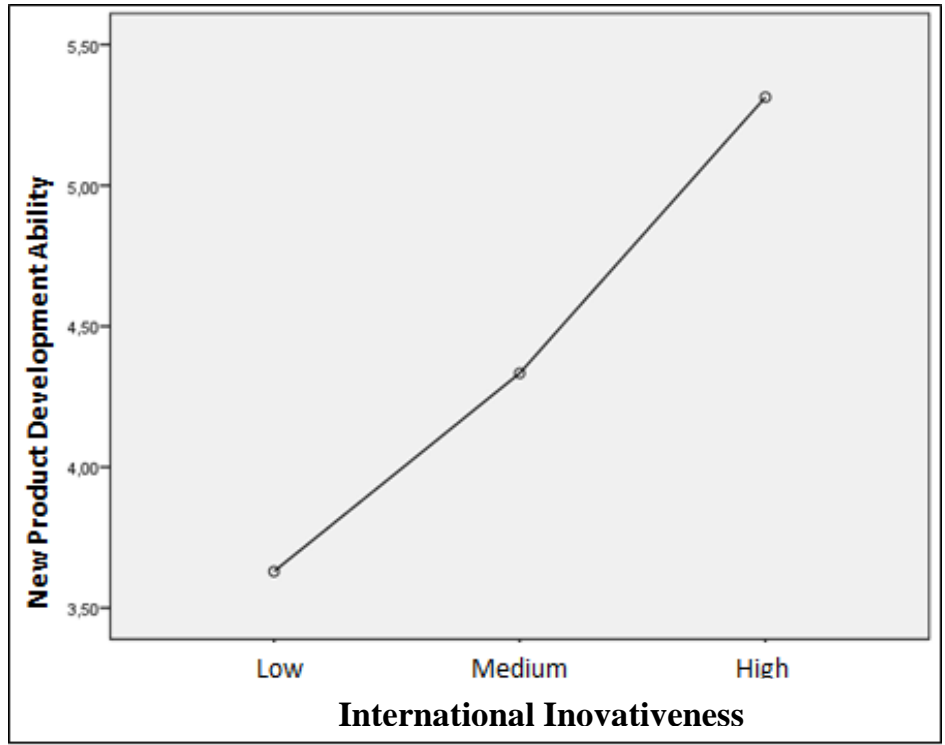

Source: Elaborated by the authors, based on the results of SPSS processing.

\subsubsection{Differences in the Export Profile Model}

Based on the criteria of Table 1 and considering the number of cases in the sample, two "exporting companies" categories were created, including the ones with most operations in the national territory and the exporting companies with most operations in the international territory. Four categories of measures of internationalization level were established to study the subjects of operations, national activities, export activities and international activities.

The variable "Model" was created from such categorization, which comprises the average performance in all constructs of the model, with the final variables. The tests demonstrated that there is significant difference by the type of operation in the overall performance of the model, varying the average between 59\% and 68\%, as shown in Figure 4. 
Figure 4

ANOVA results by exportation profile

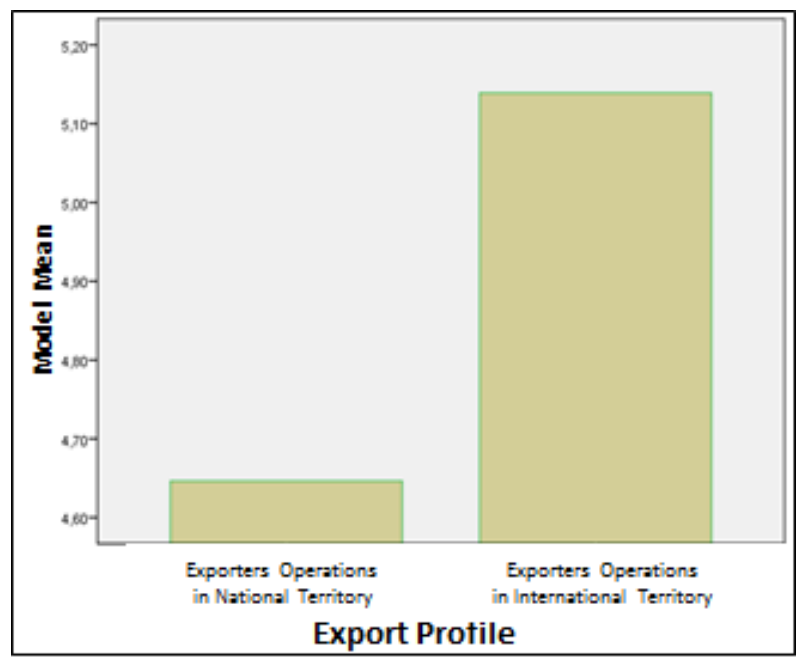

Source: Elaborated by the authors, based on the results of SPSS processing.

Through the processing of ANOVA, the difference in results between the constructs of Export Profile shows that the overall organizational performance versus the Export Profile opens spaces for new investigations, dealing with theoretical but also managerial questions. The first ones stand out as external contact capabilities with the market, and the second ones of character and internal domain to the organization. They consider that the average performance of non-exporting companies in those constructs, and specifically with NPDA, should still be lower, which do not present the same degree of requirements that the international market establishes, and of those of small size. The analysis of NPDA with the variable International Inovativeness presents the contributions of this variable for the internationalization and competitiveness of the companies in a global scenario.

\subsubsection{Relations between New Product Development Ability, Integration and International Inovativeness}

Complementary analysis show higher levels of integration between Research and Development $(R \& D)$, Marketing and Sales, Operations, where the integration of the NPD have a positive relation with the Ability in NPD as well as a greater level of Innovation in Markets. In this analysis, clusters of companies were generated according to their integration level of NPD (variable 37) and related to the performance of both the NPDA and IEO_LII. According to the variance analysis, Figure 5 shows that there are positive associations that reinforce managerially the importance of the role of integration in NPDP and its relation in NPDA and in International Inovativeness. As this measure comprises the level of integration between R\&D/Engineering, Operations, Marketing and Sales, a cross-functional integration is demonstrated as an important element or association characteristic for New Product Development 
Skills as well as for higher performance of Introduction of product innovation in the international market.

Figure 5

Level of Integration versus NPDA and IEO_LII

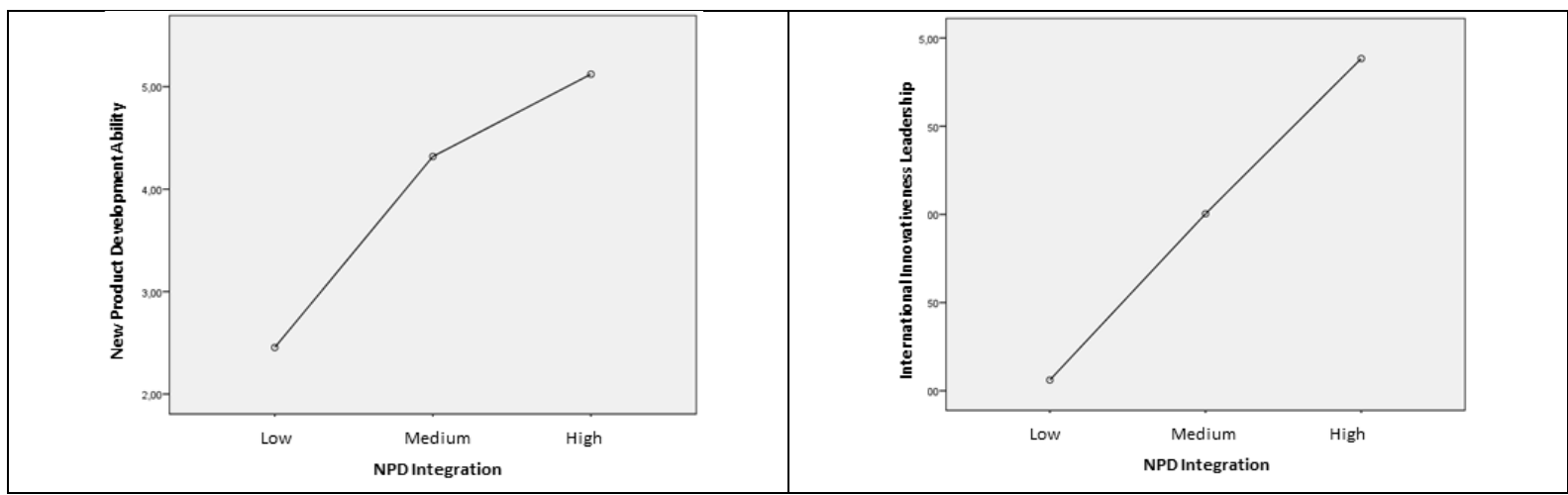

Source: Elaborated by the authors, based on the results of SPSS processing.

\subsubsection{NPDA and Export intensity}

Finally, another finding in the research concerns the relationship between NPDA and Export Intensity (variable 1). From a SPPS clusters analysis, two clusters were identified, of low and high intensity of export, with an export intensity limit of $20 \%$. Thus, low-intensity cluster companies account for $65 \%$ of the sample and have less than $20 \%$ of exports on total revenue, where high-intensity cluster companies have a share of $20 \%$ or more in total sales and account for $35 \%$ of the sample. The ANOVA analysis has identified a significant difference in the level of NPDA and the variable Model, which measures the overall performance in all constructs of the Theoretical Model, being the result of the analysis, as observed in Figure 6.

\section{Figure 6}

\section{Export Intensity and NPDA Performance}

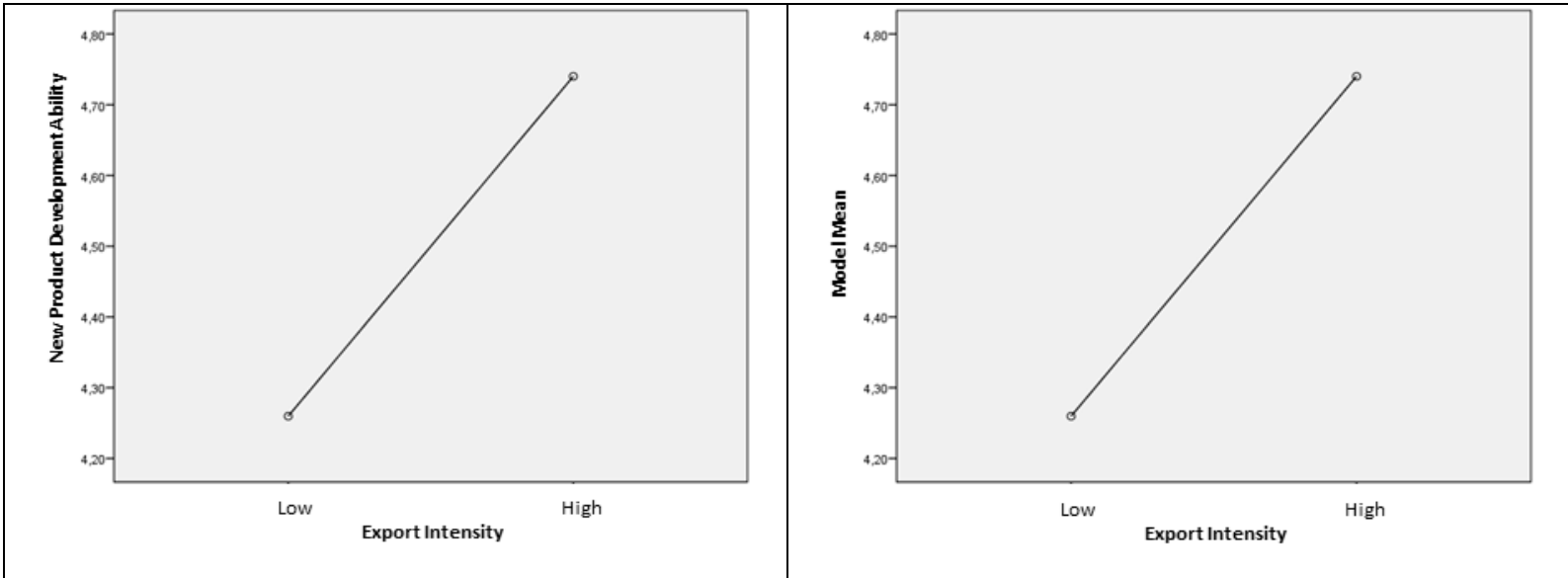

Source: Elaborated by the authors, based on the results of SPSS processing. 
Even though the NPDA measures the ability to develop new products in the context of international markets and considering that its predictive relationships can not be established, the observed associations become important to identify the organizations having a higher Export Intensity and are above the Brazilian average, according to setorial industry reports. The organizations having a higher performance in the NPDA have a positive relation with the presence of Learning Capability, Organizational Creativity, International Entrepreneurial Orientation, Reconfiguration Capability and Technological Capability. Finally, those findings are important in both theoretical and managerial perspectives, given the greater export intensity of the metalmechanic industry, and the necessity of those companies to develop competitiveness in international markets. However, during the data collection, the Brazilian currency was devalued in relation to the US dollar, or the Euro and it is important to note that the metalmechanic industry does not work necessarily deal with commodity products whose competition is based on price, but with products such as machines, equipment and components that demand higher standards of quality, safety and innovation, as well as involving a greater complexity of development.

\section{Conclusion}

Since the development of new products is essentially an information-processing activity (Kleinschmidt, De Brentani, \& Salomo, 2010), and analysing what is the association between the New Products Development Ability for International Markets and the International Inovativeness, this study observed the positive relationship between these two constructs in the context of Brazilian and medium-sized metal-mechanic manufacturing organizations.

The results present a positive relation between the New Products Development Ability of the International Market and the International Inovativeness, where organizations enhancing their capacity to develop, launch and systematically introduce new products into the market are more agile than their competitors. This companies show indications of: a) a higher level of the introduction of new product lines in the international market; b) a higher level of introduction of products (radical) in the international market; and (c) being the first to introduce new products and/or services, administrative techniques and operational technologies. Furthermore, the positive association between Performance in NPDA and Export Intensity suggests that this is an important characteristic to be developed for companies in this segment that seek to position themselves in the international market via product innovation. Although such relationships can not be characterized as predictive, the associations identified by ANOVA are relevant to future studies by Modeling Structural Equations to confirm those theoretical propositions, mainly involving NPDA, NPD integration, radical innovation, and export intensity. 
What leads the Brazilian manufacturing industry to lose competitiveness in the international market? Although external factors like industrial policy, logistics and taxes have share of explanation in the business performance, the research data suggest opportunities in the internal factors related to the determinants of the New Products Development Ability (NPDA) for the international market. The average NPDA performance of the companies in the sample stands at $54,47 \%$. This suggests an expressive potential of improvement and a necessity to increase the New Products Development Ability to achive organizational gains. Those results point out a reflection about a greater need for the development of practices and tools in this field, given the validation of the hypotheses about the relations of the constructs, which are the essence of organizational characteristics and processes. Thus, considering the related managerial need, the theoretical model is configured as an alternative management mechanism and best practices, in addition to the other management systems of the company.

Consequently, the managerial implications of the adoption of this model is observed from the NPDA results and the complementary analysis. The ANOVA tests showed that companies with higher performance in NPDA had higher export intensity and a higher level of internationalization. Therefore, the action on the predictive factors becomes a toolkit of managerial recommendation for the development of capabilities aimed at increasing the ability to develop new products for the international market and to seek leadership in innovation. In addition, such analysis leads to a managerial implication in terms of the need to overcome barriers of thought, tradition, and mechanistic organizational structure, and even as the industry and the metal-mechanic sector perceive the issue of creativity and, above all, learning and intrapreneurship, in their organizations. Such positioning can be noted in more recent studies contextualized in the electronics manufacturing sector (Ibrahim, Isa, \& Shahbudin, 2016).

If an organization is entirely committed to production and standardization and does not present any ideation, creative problem-solving involvement besides the integration of the commercial area as an input to the NPD, there will be greater difficulty in developing these dimensions. That is, the managerial implication of the model initially lies in a process dimension, but also in thinking about the actuation model itself. In terms of managerial contributions, based on the premise that NPDA is an important dimension to be developed in a company, the authors propose a set of best practices distributed in two main categories, as observed in Figure 7.

The second category refers to the Systems, Processes and Technology and they contemplate the existing methods in the managerial field that an organisation may adopt. In such case of reconfiguration dimension, the adoption of Flexible Manufacturing Systems or Flexible Manufacturing Cells are important resources for this purpose, especially for the metal-mechanic sector, which allows the expansion of its reconfiguration capability in New Products, given the changes identified in the 
market. It would not occur with the same agility with the Commitment in a highly standardized and rigid manufacturing system.

Figure 7

\section{Management best practices related to the research constructs}

\begin{tabular}{|c|c|c|}
\hline Constructs & Strategy, Culture, Models and Decisions & Systems, Processes and Tecnology \\
\hline $\begin{array}{l}\text { New Product } \\
\text { Development } \\
\text { Ability }\end{array}$ & $\begin{array}{l}\text { - To establish Strategy, Portfolio, and Innovation Budget } \\
\text { - To adopt Product Lifecycle Management } \\
\text { - To reduce NPD lead-time } \\
\text { - To adopt multifunctional teams for NPD } \\
\text { - To develop knowledge base on local and cultural reality } \\
\text { for project positioning and simultaneous launch in } \\
\text { different countries } \\
\text { - To streamline legal, financial, tax, logistics for export } \\
\text { processes in initial and expansion sales, including launch } \\
\text { partnerships }\end{array}$ & $\begin{array}{l}\text {-NPD process and search for interdepartmental } \\
\text { integration } \\
\text {-Innovation Committee } \\
\text {-Product and Process Engineering } \\
\text { •Adoption of proprietary software for development } \\
\text { and integration between R \& D / Engineering, } \\
\text { Operations and Sales / Marketing } \\
\text {-Virtual teams of idea generation, market and } \\
\text { business analysis, product development and testing, } \\
\text { seeking to reduce launch timing and increase product } \\
\text { adherence to market specifications }\end{array}$ \\
\hline $\begin{array}{c}\text { Reconfiguration } \\
\text { Capability }\end{array}$ & $\begin{array}{l}\text { - To adopt Lean Methodology (Manufacturing, Thinking, } \\
\text { Enterprise, Business Model and NPD) } \\
\text { - To extend the level of integration and reduce the level of } \\
\text { organizational complexity } \\
\text { - To expand the frequency of change of ready-made } \\
\text { product models } \\
\text { - To reduce excess inventory to reduce commitment to } \\
\text { past line mix } \\
\text { - To invest in modularity in manufacturing and mass } \\
\text { customization } \\
\text { - To adopt Product Design principles with standard parts } \\
\text { - To search for Supply Chain Flexibility }\end{array}$ & $\begin{array}{l}\text { - Flexible Manufacturing Systems } \\
\text { - Flexible Manufacturing Cells } \\
\text {-Adoption of Cloud Computing Systems } \\
\text { - Departmental horizontalization } \\
\text { - Review of change rules and bottlenecks generated by } \\
\text { ERP and legacy systems } \\
\text { - Continuous market monitoring systems with fast } \\
\text { interdepartmental design } \\
\text {-Proprietary systems to streamline hierarchical } \\
\text { decision making }\end{array}$ \\
\hline $\begin{array}{l}\text { Technological } \\
\text { Capability }\end{array}$ & $\begin{array}{l}\text { - To perform Technological Surveillance and sources of } \\
\text { financing } \\
\text { - To adopt Technological Roadmap } \\
\text { - To systematically allocate investments for technological } \\
\text { updating, via development or acquisition } \\
\text { - To do Manufacturing Investments } 4.0 \\
\text { - To do Investments in loT (Internet of Things) }\end{array}$ & $\begin{array}{l}\text { - Systems of evaluation and prioritization of the } \\
\text { technology portfolio (machinery and equipment, } \\
\text { hardware, software, materials, products, and } \\
\text { processes) } \\
\text {-Adoption of internal R \& D or with external partners } \\
\text { - University-Company interaction for technology } \\
\text { research and development }\end{array}$ \\
\hline $\begin{array}{c}\text { International } \\
\text { Entrepreneurial } \\
\text { Orientation }\end{array}$ & $\begin{array}{l}\text { - To develop organizational compensation systems that } \\
\text { encourage: proactivity, calculated risk posture, } \\
\text { intrapreneurship } \\
\text { - To do investments for prospecting and development of } \\
\text { new international business } \\
\text { - To reward collaboration for identifying new } \\
\text { opportunities and closing deals } \\
\text { - To complete definition of risk layers for allocation of } \\
\text { resources for innovation, testing and learning }\end{array}$ & $\begin{array}{l}\text {-International market intelligence } \\
\text { - Insertion in networks and participation in } \\
\text { international events } \\
\text {-Involvement with agencies such as the Export } \\
\text { Promotion Agency that allow market insertion } \\
\text {-Adoption of commercial sales pipeline to seek timing } \\
\text { and agility in business opportunities }\end{array}$ \\
\hline $\begin{array}{l}\text { Organizational } \\
\text { Creativity }\end{array}$ & $\begin{array}{l}\text { - To establish a culture that supports experimentation } \\
\text { - To invest in time to generate ideas and identify market } \\
\text { trends } \\
\text { - To develop organizational and physical stimuli for } \\
\text { creativity in the work environment } \\
\text { - To develop environments with diversity (physical and } \\
\text { human) for generating ideas and solving problems in a } \\
\text { creative way }\end{array}$ & $\begin{array}{l}\text { - Capture, evaluation, and recognition of internal and } \\
\text { external ideas } \\
\text { - Ideation Environments (Labs) } \\
\text { - University-Company interaction for ideation } \\
\text {-Adoption of proprietary software for information } \\
\text { management of ideations }\end{array}$ \\
\hline $\begin{array}{l}\text { Learning } \\
\text { Capability }\end{array}$ & $\begin{array}{l}\text { - To invest time for the development of employees' } \\
\text { competences, with active learning strategies and in } \\
\text { internal and external environments to the organization } \\
\text { - To invest time for group learning development } \\
\text { - To encourage team communication as well as shared } \\
\text { vision and systemic socialization }\end{array}$ & $\begin{array}{l}\text {-Knowledge Management and Communities of } \\
\text { Practice, physical and virtual } \\
\bullet \text { organizational communication } \\
\text { • Environments of socialization, sharing of experiences } \\
\text { and construction of organizational knowledge } \\
\text { •Invest in access to external and international } \\
\text { knowledge }\end{array}$ \\
\hline
\end{tabular}

Source: Elaborated by the authors. 
Thus, those managerial contributions support companies with the strategic motivations seeking an "Innovation in the international market" positioning. It is also worth noting that the data of this investigation were collected in an economic period of significant turbulence and instability in the Brazilian economic scenario. In this sense, the proposed Theoretical Model and the complementary analysis need to be understood from such context. Furthermore, such analysis does support the investment and development, by the medium and large organizations of the Brazilian metal-mechanic sector, of the NPDA and their antecedent practices, by seeking greater sectorial competitiveness through the internationalization and innovation of products.

The analysis also represents key theoretical contributions and insights for new studies, such as the Learning Capability with the level of Radical Innovation, relations between the concepts of NPDA, integration of NPD and the Innovation in International Markets, and positive association with the export's intensity performance. Considering points of convergence and integration with other research and topics, NPDA extends a research agenda in both macro and micro level. Therefore, NPDA can also be related in the context of Industry 4.0 Maturity Level (Pacchini, Santos, Logiudice, \& Lucato 2020), IT and Lean Manufacturing Maturity (Testa Filho, Mattos, \& Alliprandini, 2019) and Servitization Maturity (Almeida \& Cauchick-Miguel, 2018). Considering the aspects as learning capacity, organizational creativity, entrepreneurial orientation and technological and reconfiguration capacity, is recommended advance the research about the the effects Agile Teams and Teams Adaptability to NPDA (Grass, Backmann, \& Hoegl, 2020), Team Diversity to NPDA (Weiss, Backmann, Razinskas, \& Hoegl 2019), Market and Technical Information Generation and NPDA (Cui \& Xiao, 2018), Stream-Concentration, that is differences among NPD team members in terms of familiarity with the knowledge domain of the new product in development (Forti, Sobrero, \& Vezzulli, 2020), NPDA level and NPD Cycle Time (Griffin, Langerak, \& Eling, 2019) as well Contextual Ambidexterity and Knowledge Base (Ko and Liu, 2018).

Such relationships do represent new opportunities for future research in this area. Therefore, these results have both theoretical and managerial implications for New Product Development field. As theoretical, NPDA can be argued as important construct or capability to be applied in future studies, not only as a determinant (cause), but as well researchers are also encouraged to understand its antecedents (NPDA as effect), due its explanation power. Also, considering its relationship with International Inovativeness, NPDA contributes as an important metric and unidimensional construct, especially in studies involving international markets, and it is a theoretical gap. For practitioners, this study contributes with the managerial best practices associated with NPDA, that compreehends a systemic approach for resource allocation toward company competitiveness trought innovation. NPDA it is a fundamental process, both business and industrial, for manufacturing company competitiveness in the context of Industry 4.0 and Innovation. Althougth, these knowledge-based capabilities, learning capability, organizational creativy, international entrepreneurial orientation, technological capability, 
reconfiguration capability and new product development ability can be researched and developed not only in firm level: further understandment in University-Industry relationship and Innovation Ecosystems level are suggested for future research, and how Artificial Intelligence Capabilities are related to these constructs. Therefore, further analysis on how external networks and technologies can expand and augment these specific industry capabilities is suggested as a research agenda in NPD and Innovation field.

\section{Acknowledgements}

This research project was funded by CNPq - National Council for Scientific and Technological Development (Brazil) and CAPES - Brazilian Federal Agency for Support and Evaluation of Graduate Education.

\section{References}

Afgan, N. H., \& Carvalho, M. G. (2010). The knowledge society: a sustainability paradigm. Cadmus. DOI: http://cadmus.newwelfare.org/2010/10/23/the-knowledge-society-a-sustainabilityparadigm/4/

Akgün, A. E, Keskin, H., \& Byrne, J. C. (2010). Procedural justice climate in new product development teams: antecedents and consequences. Journal of Product Innovation Management, 27 (7). DOI: https://doi.org/10.1111/j.1540-5885.2010.00773.x

Almeida, L., da Sllva, M. T., \& Cauchick-Miguel, P. A. (2018). Servitization in an airplane company: the relation between services and new product development/Servitizacao em uma empresa fabricante de aeronaves: a relacao dos servicos com o desenvolvimento de produto. Revista Exacta, 16(4), 59-78. DOI: https://go.gale.com/ps/i.doid=GALE\%7CA596317388\&sid=googleScholar\&v=2.1\&it=r\&linkacc ess $=$ abs\&issn $=16785428 \& p=A O N E \& s w=w$

Amabile, T. M., e R. Conti. (1999). Changes in the work enviroment for creativity during downsizing. Academy of Management Journal, 42(6), 630-640. DOI: https://doi.org/10.2307/256984

Amabile, T. M. (1996). Creativity and innovation in organizations. Harvard Business School Background Note. Boston: Harvard Business School.

Bendoly, E., Bharadwaj, A., \& Bharadwaj, S. (2012). Complementary drivers of new product development performance: Cross-functional coordination, information system capability, and intelligence quality. Production and Operations Management, 21(4), 653-667. DOI: https://doi.org/10.1111/j.1937-5956.2011.01299.x

Bharadwaj, S., \& Menon, A. (2000). Making innovation happen in organizations: individual creativity mechanisms, organizational creativity mechanisms or both?. Journal of Product Innovation Management: An International Publication of the Product Development \& Management Association, 17(6), 424-434. DOI: https://doiorg.ez314.periodicos.capes.gov.br/10.1016/S0737-6782(00)00057-6 
Bhuiyan, N. (2011). A framework for successful new product development. Journal of Industrial Engineering and Management (JIEM), 4(4), 746-770. DOI: https://doi.org/10.3926/jiem.334

Boada-Grau, J., Sánchez-García, J. C., Prizmic-Kuzmica, A. J., \& Vigil-Colet, A. (2014). Spanish adaptation of the Creative Potential and Practised Creativity scale (CPPC-17) in the workplace and inside the organization. Psicothema, 26(1), 55-62. DOI: https://doi.org/10.7334/psicothema2013.68

Booz, Allen \& Hamilton. (1982). New product management for the 1980's. New York: Booz, Allen \& Hamilton.

Brattström, A., Löfsten, H., \& Richtnér, A. (2012). Creativity, trust and systematic processes in product development. Research Policy, 41(4), 743-755. DOI:

https://doi.org/10.1016/j.respol.2011.12.003.

Bstieler, L. (2006). Trust formation in collaborative new product development. Journal of Product Innovation Management, 23(1), 56-72. DOI: https://doi.org/10.1111/j.15405885.2005.00181.x.

Clark, K, \& Fujimoto, T. (1991). Product development performance. Boston: Harvard Business School Press. Boston, MA.

Cooper, R. G., \& Edgett, S. J. (2008). Maximizing productivity in product innovation. ResearchTechnology Management, 51(2), 47-58. DOI: https://wwwwebofscience.ez314.periodicos.capes.gov.br/wos/woscc/full-record/WOS:000253393000011

Cooper, R. G. (1990). Stage-gate systems: a new tool for managing new products. Business horizons, 33(3), 44-54. DOI: https://doi.org/10.1016/0007-6813(90)90040-I

Cooper, R. G. (2008). Perspective: The stage-gate ${ }^{\circledR}$ idea-to-launch process-update, what's new, and nexgen systems. Journal of product innovation management, 25(3), 213-232. DOI: https://doi.org/10.1111/j.1540-5885.2008.00296.x

Cooper, R. G. (2019). The Drivers of New-Product Development. Industrial Marketing Management, 76, 36-47. DOI: https://doi.org/10.1016/j.indmarman.2018.07.005

Cooper, R. G., Edgett, S. J., \& Kleinschmidt, E. J. (2002). Portfolio management: fundamental to new product success. The PDMA toolbook for new product development, 1, 331-364. DOI: https://www.researchgate.net/profile/Elko-Kleinschmidt2/publication/238676288_Portfolio_Management__Fundamental_to_New_Product_Success/links/556f138308aeccd7774108f5/PortfolioManagement-Fundamental-to-New-Product-Success.pdf

Cordes, P., \& Hülsmann, M. (2014). How knowledge-based dynamic capabilities help to avoid and cope with path dependencies in the electric mobility sector. In Evolutionary Paths Towards the Mobility Patterns of the Future, (pp. 169-186). Springer, Berlin, Heidelberg. DOI: https://doi.org/10.1007/978-3-642-37558-3_11

Cousins, P. D., Lawson, B., Petersen, K. J., \& Handfield, R. B. (2011). Breakthrough scanning, supplier knowledge exchange, and new product development performance. Journal of Product Innovation Management, 28(6), 930-942. DOI: https://doi.org/10.1111/j.1540-

5885.2011.00854.x 
Covin, J. G., \& Miller, D. (2014). International entrepreneurial orientation: Conceptual considerations, research themes, measurement issues, and future research directions. Entrepreneurship Theory and Practice, 38(1), 11-44. DOI: https://doi.org/10.1111/etap.12027.

Cui, A. S., \& Xiao, Y. (2019). The role of market and technical information generation in new product development. Journal of Product Innovation Management, 36(3), 305-330. DOI: https://doi.org/10.1111/jpim.12479

Crespi, G., \& Zuniga, P. (2012). Innovation and productivity: evidence from six Latin American countries. World development, 40(2), 273-290. DOI: https://doi.org/10.1016/j.worlddev.2011.07.010

Dayan, M., \& Elbanna, S. (2011). Antecedents of team intuition and its impact on the success of new product development projects. Journal of Product Innovation Management, 28(s1), 159-174. DOI: https://doi.org/10.1111/j.1540-5885.2011.00868.x

Dimitratos, P., Voudouris, I., Plakoyiannaki, E., \& Nakos, G. (2012). International entrepreneurial culture-Toward a comprehensive opportunity-based operationalization of international entrepreneurship. International Business Review, 21(4), 708-721. DOI: https://doi.org/10.1016/j.ibusrev.2011.08.001

Dixit, G. K., \& Nanda, T. (2011). Strategic alignment of organizational culture and climate for stimulating innovation in SMEs. International Journal of Innovation, Management and Technology, 2(1), 77. DOI: http://www.ijimt.org/papers/109-M500.pdf

Durmuşoğlu, S. S., Calantone, R. J., \& McNally, R. C. (2013). Ordered to innovate: A longitudinal examination of the early periods of a new product development process implementation in a manufacturing firm. Journal of Product Innovation Management, 30(4), 712-731. DOI: https://onlinelibrary.wiley.com/doi/abs/10.1111/jpim.12016

Ekvall, G. (1997). Organizational conditions and levels of creativity. Creativity and innovation management, 6(4), 195-205. DOI: https://onlinelibrary.wiley.com/doi/abs/10.1111/14678691.00070

Forti, E., Sobrero, M., \& Vezzulli, A. (2020). Continuity, change, and new product performance: the role of stream concentration. Journal of Product Innovation Management, 37(3), 228-248. https://doi.org/10.1111/jpim.12521

Grass, A., Backmann, J., \& Hoegl, M. (2020). From empowerment dynamics to team adaptability: Exploring and conceptualizing the continuous agile team innovation process. Journal of Product Innovation Management, 37(4), 324-351. DOI: https://doi.org/10.1111/jpim.12525

Griffin, A., Langerak, F., \& Eling, K. (2019). The evolution, status and research agenda for the future of research in NPD cycle time. Journal of Product Innovation Management, 36(2), 263-280. DOI: https://doi.org/10.1111/jpim.12484

Gilson, L. L., Mathieu, J. E., Shalley, C. E., \& Ruddy, T. M. (2005). Creativity and standardization: complementary or conflicting drivers of team effectiveness?. Academy of Management journal, 48(3), 521-531. DOI: https://journals.aom.org/doi/abs/10.5465/AMJ.2005.17407916 
Goedhuys, M., \& Veugelers, R. (2012). Innovation strategies, process and product innovations and growth: Firm-level evidence from Brazil. Structural change and economic dynamics, 23(4), 516-529. DOI: https://www.sciencedirect.com/science/article/pii/S0954349X11000178

Hair, J. F., Black, W. C., Babin, B. J., Anderson, R. E., \& Tatham, R. L. (2009). Análise multivariada de dados. Bookman editora. ISBN: 9788577804023.

Urbancova, H. (2013). Competitive advantage achievement through innovation and knowledge. Journal of competitiveness, 5(1). DOI: https://pdfs.semanticscholar.org/7877/52abf09876821863596a5739a6715eaaee72.pdf

Hawass, H. H. (2010). Exploring the determinants of the reconfiguration capability: a dynamic capability perspective. European Journal of Innovation Management. DOI: https://doi.org/10.1108/14601061011086276

Holahan, P. J., Sullivan, Z. Z., \& Markham, S. K. (2014). Product development as core competence: How formal product development practices differ for radical, more innovative, and incremental product innovations. Journal of Product Innovation Management, 31(2), 329-345. DOI: https://onlinelibrary.wiley.com/doi/abs/10.1111/jpim.12098

Ibrahim, H. I., Isa, A., \& Shahbudin, A. S. M. (2016). Organizational support and creativity: The role of developmental experiences as a moderator. Procedia Economics and Finance, 35, 509-514. DOI: https://doi.org/10.1016/S2212-5671(16)00063-0

Im, S., Montoya, M. M., \& Workman Jr, J. P. (2013). Antecedents and consequences of creativity in product innovation teams. Journal of Product Innovation Management, 30(1), 170-185. DOI: https://doi.org/10.1111/j.1540-5885.2012.00887.x

Kahn, K. B. (2001). Market orientation, interdepartmental integration, and product development performance. Journal of Product Innovation Management: AN INTERNATIONAL PUBLICATION OF THE PRODUCT DEVELOPMENT \& MANAGEMENT ASSOCIATION, 18(5), 314-323. DOI: https://doi.org/10.1111/1540-5885.1850314

Kaminski, P. C., de Oliveira, A. C., \& Lopes, T. M. (2008). Knowledge transfer in product development processes: a case study in small and medium enterprises (SMEs) of the metal-mechanic sector from Sao Paulo, Brazil. Technovation, 28(1-2), 29-36. DOI: https://doi.org/10.1016/j.technovation.2007.07.001

Kemper, J., Schilke, O., \& Brettel, M. (2013). Social capital as a microlevel origin of organizational capabilities. Journal of Product Innovation Management, 30(3), 589-603. DOI: https://doi.org/10.1111/jpim.12004

Kim, J. Y., Wong, V., \& Eng, T. Y. (2005). Product variety strategy for improving new product development proficiencies. Technovation, 25(9), 1001-1015. DOI: https://doi.org/10.1016/j.technovation.2004.02.011

Kleinschmidt, E., De Brentani, U., \& Salomo, S. (2010). Information processing and firm-internal environment contingencies: Performance impact on global new product development. Creativity and Innovation Management, 19(3), 200-218. DOI: https://doi.org/10.1111/j.14678691.2010.00568.x 
Ko, W. W., \& Liu, G. (2019). How information technology assimilation promotes exploratory and exploitative innovation in the small-and medium-sized firm context: the role of contextual ambidexterity and knowledge base. Journal of product innovation management, 36(4), 442466. DOI: https://doi.org/10.1111/jpim.12486

Koksal, M. H. (2014). The differences between successful and unsuccessful new manufacturing products in international markets: Evidence from Turkey. Asia Pacific Journal of Marketing and Logistics. DOI: https://doi.org/10.1108/APJML-04-2013-0047

Lee, K. B., \& Wong, V. (2010). New product development proficiency and multi-country product rollout timeliness. International Marketing Review. DOI:

https://doi.org/10.1108/02651331011020393

Lee, Y., Lin, B. W., Wong, Y. Y., \& Calantone, R. J. (2011). Understanding and managing international product launch: A comparison between developed and emerging markets. Journal of Product Innovation Management, 28(s1), 104-120. DOI: https://doi.org/10.1111/j.15405885.2011.00864.x

Leenders, R. T. A., Van Engelen, J. M., \& Kratzer, J. (2007). Systematic design methods and the creative performance of new product teams: Do they contradict or complement each other?. Journal of Product Innovation Management, 24(2), 166-179. DOI: https://onlinelibrary.wiley.com/doi/abs/10.1111/j.1540-5885.2007.00241.x

Li, Y. H., \& Huang, J. W. (2012). Ambidexterity's mediating impact on product development proficiency and new product performance. Industrial Marketing Management, 41(7), 1125-1132. DOI: https://doi.org/10.1016/j.indmarman.2012.05.002

Malhotra, N. K., Birks, D., Wills, P. (2012). Marketing research: applied approach. (4). New York: Pearson.

Menguc, B., \& Auh, S. (2010). Development and return on execution of product innovation capabilities: The role of organizational structure. Industrial marketing management, 39(5), 820-831. DOI: https://doi.org/10.1016/j.indmarman.2009.08.004

Millson, M. R. (2012). An Empirical Exploration of the New Product Process Proficiency-New Product Success Relationship. International Journal of Business and Information, 7(1), 1. DOI: https://search.proquest.com/openview/6d3e7bbf0c63bea80e4da9ba2f8edba7/1?pqorigsite $=$ gscholar $\& \mathrm{cbl}=236248$

Pacchini, A. P. T., da Silva Santos, J. C., Logiudice, R., \& Lucato, W. C. (2020). Indústria 4.0: barreiras para implantação na indústria brasileira. Exacta, 18(2), 278-292. DOI: https://doi.org/10.5585/ExactaEP.v18n2.10605

Panizzon, M., Milan, G. S., Dorion, E. C. H., \& Coallier, F. (2020). The main determinants of new product development ability for international markets: An empirical study on brazilian manufacturing export companies. Journal of Engineering and Technology Management, 57, 101569. DOI: https://doi.org/10.1016/j.jengtecman.2020.101569

Park, K., \& Kim, B. K. (2013). Dynamic capabilities and new product development performance: Korean SMEs. Asian Journal of Technology Innovation, 21(2), 202-219. DOI: https://doi.org/10.1080/19761597.2013.866308 
Perin, M. G., Sampaio, C. H., Barcellos, M. D. D., \& Kügler, J. O. (2010). The moderating effects of innovativeness on new product development ability. Produto \& produção. Porto Alegre, RS. Vol. 11, n. 3 (out. 2010), p. 19-28. DOI: https://www.lume.ufrgs.br/handle/10183/29217

Rosenbusch, N., Brinckmann, J., \& Bausch, A. (2011). Is innovation always beneficial? A meta-analysis of the relationship between innovation and performance in SMEs. Journal of business Venturing, 26(4), 441-457. DOI: https://doi.org/10.1016/j.jbusvent.2009.12.002

Sheng, M. L., \& Chien, I. (2016). Rethinking organizational learning orientation on radical and incremental innovation in high-tech firms. Journal of Business Research, 69(6), 2302-2308. DOI: https://doi.org/10.1016/j.jbusres.2015.12.046

Slater, S. F., Mohr, J. J., \& Sengupta, S. (2014). Radical product innovation capability: Literature review, synthesis, and illustrative research propositions. Journal of Product Innovation Management, 31(3), 552-566. DOI: https://doi.org/10.1111/jpim.12113

Sok, P., O'Cass, A., \& Sok, K. M. (2013). Achieving superior SME performance: Overarching role of marketing, innovation, and learning capabilities. Australasian Marketing Journal (AMJ), 21(3), 161-167. DOI: https://doi.org/10.1016/j.ausmj.2013.04.001

Song, X. M., \& Parry, M. E. (1997). A cross-national comparative study of new product development processes: Japan and the United States. Journal of marketing, 61(2), 1-18. DOI: https://doi.org/10.2307/1251827

Subramaniam, M., \& Youndt, M. A. (2005). The influence of intellectual capital on the types of innovative capabilities. Academy of Management journal, 48(3), 450-463. DOI: https://doi.org/10.5465/AMJ.2005.17407911

Sun, Y., \& Du, D. (2010). Determinants of industrial innovation in China: Evidence from its recent economic census. Technovation, 30(9-10), 540-550. DOI: https://doi.org/10.1016/j.technovation.2010.05.003

Testa Filho, N., Mattos, C. A. de., \& Alliprandini, D. (2019). Analysis of the relationship between information technology, lean manufacturing practices and operational performance. Exacta, 17(4), 314-328. DOI: https://doi.org/10.5585/Exacta.v17n4.8631

Tzokas, N., Kim, Y. A., Akbar, H., \& Al-Dajani, H. (2015). Absorptive capacity and performance: The role of customer relationship and technological capabilities in high-tech SMEs. Industrial Marketing Management, 47, 134-142. DOI: https://doi.org/10.1016/j.indmarman.2015.02.033

Voelker, T. A. (2008). The impact of social capital and dynamic capabilities on new product development: an investigation of the entertainment software industry. University of North Texas. DOI: https://search.proquest.com/openview/edac8a001e1cbd4eff9ba6ddd27e4b4d/1?pqorigsite $=$ gscholar $\& \mathrm{cbl}=18750$

Vorhies, D. W., Morgan, R. E., \& Autry, C. W. (2009). Product-market strategy and the marketing capabilities of the firm: impact on market effectiveness and cash flow performance. Strategic Management Journal, 30(12), 1310-1334. DOI: https://doi.org/10.1002/smj.798

Wan, D., Ong, C. H., \& Lee, F. (2005). Determinants of firm innovation in Singapore. Technovation, 25(3), 261-268. DOI: https://doi.org/10.1016/S0166-4972(03)00096-8 
Wang, C., \& Kafouros, M. I. (2009). What factors determine innovation performance in emerging economies? Evidence from China. International Business Review, 18(6), 606-616. DOI: https://doi.org/10.1016/j.ibusrev.2009.07.009

Weiss, M., Backmann, J., Razinskas, S., \& Hoegl, M. (2018). Team diversity in innovation—Salient research in the journal of product innovation management. DOI: https://doi.org/10.1111/jpim.12465

Zhou, H., \& Uhlaner, L. M. (2009). Predicting Innovation in SMEs: A Knowledge-Based Dynamic Capabilities Perspective. Available at SSRN 1532796. DOI: https://papers.ssrn.com/sol3/papers.cfm?abstract_id=1532796 